\title{
The Role of Immune System in Depression Disorder
}

\author{
Fatemeh Hoseinzadeh'1, Porya Hassan Abadi' ${ }^{2}$ Mehdi Agheltar'1, Arvin Aghayinejad ${ }^{3}$, \\ Farnaz Torabian ${ }^{3}$, Arash Akhavan Rezayat ${ }^{4}$, Farzad Akbarzadeh ${ }^{1}$, Hamid Reza Rahimi ${ }^{*}$ \\ ${ }^{1}$ Department of Psychiatry, School of Medicine, Mashhad University of Medical Sciences, Mashhad, Iran \\ ${ }^{2}$ Student of Medicine, School of Medicine, University of Birmingham, Birmingham, UK \\ ${ }^{3}$ School of Medicine, Islamic Azad University of Mashhad, Mashhad, Iran \\ ${ }^{4}$ Student Research Committee, Faculty of Medicine, Mashhad University of Medical Sciences, Mashhad, Iran \\ ${ }^{5}$ Department of Modern Sciences \& Technologies, School of Medicine, Mashhad University of Medical Sciences, Mashhad, Iran \\ Email: *rahimihr891@mums.ac.ir
}

How to cite this paper: Hoseinzadeh, F., Abadi, P.H., Agheltar, M., Aghayinejad, A., Torabian, F., Rezayat, A.A., Akbarzadeh, F. and Rahimi, H.R. (2016) The Role of Immune System in Depression Disorder. Health, 8, 1726-1743.

http://dx.doi.org/10.4236/health.2016.815167

Received: May 23, 2016

Accepted: December 6, 2016

Published: December 9, 2016

Copyright $\odot 2016$ by authors and Scientific Research Publishing Inc. This work is licensed under the Creative Commons Attribution International License (CC BY 4.0).

http://creativecommons.org/licenses/by/4.0/

\section{(c) (i) Open Access}

\begin{abstract}
In order to diagnose a major depressive disorder, patients must have at least 5 depressive symptoms out of 9 criteria, present for at least two weeks. Depressive symptoms include absence of concentration, fatigue and suicidal ideation. The intensity of depression symptoms affects the severity of depression and the degree of the impact on the quality of life. Major depressive disorders (MDD) are defined as a significant health problem, and are estimated to rise in prevalence in the future years. Immune cytokine, associated with major depression for instance, is the interleukin IL-6 and tumor necrosis factor (TNF- $\alpha$ ) which is defined as pro-inflammatory cytokines, can activate an inflammatory response. The effects of other inflammatory cytokines on the central nervous system are of controversy. There is an increasing interest about the effect of cytokines derived from innate immune system on the brain and behavior. Cytokines are defined as large sized proteins, mainly produced by immune cells. Two subtypes of cytokines exist: pro-inflammatory cytokines, facilitating inflammatory responses and neural activities; and anti-inflammatory cytokines, inhibiting inflammatory processes. Besides microglia and astrocytes, immune cells such as monocytes, macrophages, and lymphocytes also produce cytokines. At the times of immunological alterations, infections or inflammation, cytokines will be in an activated form. The main goal of the current review study is to investigate the role of the immune system in the depression disorder.
\end{abstract}

\section{Keywords}

Depression, Cytokines, IL-6, TNF- $\alpha$, Psychoneuroimmunology

\section{Introduction}

Depression, as a mental disorder, is a major public health concern. In some societies, 
the prevalence of depression is about $20 \%$ [1] [2]. The estimations are showing rise of the depression's incidence in the future [3]. Many studies have indicated a relationship between the immune system and the neural system.

Cytokines mediate immune system's response to injury, infections and etc. [4]. They also have an important role in immune responses, neurogenesis and neuroprotection which are mediated by macrophages and monocytes [5].

Studies have shown that not only the increase of the immune cytokines can be a trigger to depression, but also, depression can stimulate the immune system and release cytokine and interleukins [3] [5] [6]. Although depression decreases proliferation of B cell and $\mathrm{T}$ cells and reduces natural killer cell activity, it up-regulates serum levels of interleukins and increases the cellular response of the immune system [1].

On the other hand, inflammatory cytokine can lead to a major depressive episode in the physically ill patient. Cytokine and interleukins that are raised in infections and trauma induce ill symptoms, like malaise, weakness and loss of interest in the physical activity, but more importantly it can trigger depressive symptoms [7].

Among the immunologic factors, interleukin 6 and the tumor necrosis factor $\alpha$ are increased more compared to other cytokines. The elevation of these cytokines in a normal functioning body is abnormal [8].

In this study, we review the relationship between the immune system and depression and then discuss the role of cytokines in the depression, and their effects on neuropeptides and neural growth factors.

\section{Psychoneuroimmunology}

There are two pathways between the brain and immune system namely, autonomic nervous system and neuroendocrine outflow mediated by the pituitary gland. The pathways are defined as bidirectional. For instance, Besedovsky et al. reported that immune system activation occurs concurrently with the alterations in the hypothalamic, endocrine and autonomic processes [9].

Data confirms that the signals produced by an activated immune system, are released and are received by the CNS (central nervous system). While immune cells activate, they generate cytokines. Besides their role in regulating cellular interactions, they also have some links with the CNS and thus, changes in the behavior. Some cytokines, including IL-1, IL-2, IL-6, Interferon- $\gamma$ and tumor necrosis factor (TNF) lead to activation of the HPA-axis (hypothalamic-pituitary-adrenal) [10]. Cytokines affect the neurotransmitter system via various pathways [11] [12].

The pathways aforementioned are monoaminergic system impairments, HPA-axis dysfunction, growth factor changes, alteration in neuropeptides and neurogenesis decline, while inflammatory cytokines can impact on the sited approaches [13] [14] [15] [16] [17].

\section{Inflammatory State and Depression}

The relationship between cytokines and inflammatory model with depression has ex- 
isted for a long time as an immune-based model of depression [7] [18] [19].

Based on mentioned model, a rise in the pro-inflammatory cytokines (PICs) and a decline in anti-inflammatory cytokines (AICs) are hypothesized as the pro-inflammatory state, which have been linked with depression-like behavior in both human and clinical animal experiments. The role of inflammatory state can be addressed in a number of ways such as hippocampal (HC) neuroplasticity impairment, HC oxidative stress enhancement, decrease in the levels of serotonin which will lead to the production of neurotoxic serotonergic metabolites, including 3-hydroxykynurenine (3-HK) and Guinolinic acid (QA) [7] [19] [20] [21] [22]. Inflammatory model which has been defined in the depression, has hypothesized that, level of PICs such as TNF- $\alpha$, IL-6, IFN- $y$ and IL-1B is correlated to depression in clinical and pre-clinical experiments [7] [18] [19]. Data on a rodent model illustrated that about $50 \mu \mathrm{g} / \mathrm{kg}$ of PICs (such as IL-1, IL-6, IL-2, TNF- $\alpha$, IFN- $\gamma$ ) is defined as a threshold level for depression like behavior [21] [23].

Human experiments and animal models have demonstrated that, "direct administration of the Th1 promoting cytokines IFN and IL-2 may lead to a phenotypically depression-like syndrome [24]". Dowlati et al. found that there exists a relationship between clinical depression and a pro-inflammatory state. Based on this Meta-analysis, levels of TNF- $\alpha$ and IL- 6 are higher in the group of patients with depression compared with the control group. Meta-analysis was performed by Hiles et al. shows higher concentrations of IL-6 in depression [25].

Additionally, rise of inflammatory markers such as CRP, IL- 6 , and TNF- $\alpha$, have been reported in a cross-sectional study assessing 2415 participants [26]. Maes et al. have accomplished a cross-sectional survey showing a positive correlation between levels of inflammatory markers (TNF- $\alpha$ and IL-1) and the extent of depressive episodes [27].

Three major clinical courses after an episode of depression are full remission, partial resolution, and progressive trend in chronic depression. If full or partial resolution happens, anti-inflammatory or immune biomarkers have the ability to reduce the neuro inflammation [3]. Prospective cohort studies have compared cytokine's profile in depressed subjects and a control group [28]. This study which included 50 medication-free MDD patients showed that they have higher serum concentration of IL-1B, IL-1Ra, IL-5, IL-6, IL-7, IL-8, IL-10, granulocyte-colony stimulating factor (G-CSF) and IFN-y in comparison with control subjects. Some anti-depressants such as SSRIs, are able to reduce the levels of IL- 6 and TNF- $\alpha$ that is raised in the patients with depression, however, other anti-depressants are not able to reduce PCIs [3].

Some cases of idiopathic depression with no co-morbid conditions showed an increase in the circulating pro-inflammatory biomarkers [8] [29] [30] [31]. Many studies done on idiopathic major depression showed that circulating biomarkers such as TNF- $\alpha$, IL-6, their soluble receptors, and CRP have risen in this group of patients [29] [30] [31]. Furthermore, CSF examination in depressed patients showed an increase in the level of some cytokines [32] [33] [34].

Levine et al. assessed CSF concentration of IL-1B, IL-6, and TNF- $\alpha$, IL-6, their so- 
luble receptors, and CRP in depressed subjects and results showed there is a higher concentration of IL-1B, lower level of IL-6, and no change in TNF-a level compared with controls [32].

A study performed by Lindqvist and colleagues found that, there is increased level of CSF IL-6 in depressed cases [32] [33]. Elevations of prostaglandin E2 level as an inflammatory mediator have been reported in the depressed case's saliva, plasma, and CSF [35] [36] [37] [38]. IFN-y can lead to behavioral symptoms leading to depression, in $30 \%-50 \%$ of treated patients; this effect is however, dose-dependent [39] [40] [41] [42].

\section{Cytokines in Depression}

Immune responses in injuries, infections or other stressful situations are regulated by cytokines and chemokines [43].

Cytokines as pleiotropic molecules, play a significant role in inflammatory responses. Excep for this, they also have a remarkable role in the neurogenesis and neuro-protection processes. They are considered as an important factor for brain development. Furthermore, cytokines can support neuronal integrity, neurogenesis and synaptic remodeling [19] [44] [45]. However, chronic exposure to inflammatory cytokines with high concentration may lead to neuropsychiatric dysfunction with depression being a common one. Compared to the general population, patients with medical illnesses with elevated level of inflammatory cytokines were more prone to depression [46] [47].

Well known pro-inflammatory cytokines are IL-1B, IL-6, and TNF- $\alpha$. On the other hand, most widely investigated anti-inflammatory cytokines are IL-4 and IL-10 [5]. During CNS injuries such as trauma, infections and ischemic attacks, cytokines will be activated via glial cells [48] [49].

The depression that is induced by IFN- $\alpha$ is closely similar to major depression. As an immunological marker, IFN- $\alpha$ can directly impact the central nervous system (CNS) or it may do so by activating central or peripheral pro-inflammatory cytokines [50] [51]. Pro-inflammatory cytokines are linked closely to the hippocampal glucocorticoid receptors (GRs) and the HPA axis. In the case of depression, elevated levels of pro-inflammatory cytokines and GR functional resistance are reported as the most investigated components.

Also, in depression, the neuro-inflammation is suggested as a factor making imbalance between oxidative stress and anti-oxidative processes. Based on the current research, cytokines and GRs, as the important factors in inflammatory and endocrine processes, have a major role in the depression [5].

Data from a study carried out in Boston, on patients suffering from MDD, depicted an elevation in the levels of cytokines such as MCP-1, IL-1a, IL-1B, IL-2, IL-6, IL-8, and IFN- $y$ in this group of patients [52]-[61]. This survey also showed a rise in the levels of granulocyte-macrophage-colony-stimulating factor (GM-CSF), MIP-1a, pro inflammatory cytokines such as IL-7, IL-15 and anti-inflammatory cytokines such as IL-4, and IL-10 [4] also, in a meta-analysis study, concentrations of IL-4 didn't have significant 
difference between depression group and non-depressed group. IL-6, TNF- $\alpha$, have a significant different between two groups however, IL-1B, IFN- $\gamma$, IL-2, IL-8 and IL-10 has no significant different between two groups [8].

Smith et al. have reported inflammation resulted from macrophages, plays an important role in pathophysiology of the depression. Macrophage secret some cytokine like IL- 6 and TNF- $\alpha$ that some evidence showed that these cytokine increase in MDD [62].

Evidences suggested a close relationship between depression and pro-inflammatory changes [63]. Levels of IL-1B, IL-6, and TNF- $\alpha$ have been reported to be increased in patients suffering from MDD [8] [64].

Results published in a meta-analysis, showed significant raise in the levels of IL- 6 and TNF- $\alpha$ in the MDD patients compared with the healthy individuals, but the levels of IL-1B, IL-2, IL-4, IL-10, and IFN- $\gamma$ have not shown any notable change [65]. IFN- $\alpha$, as an exogenous factor, can cause depression [66].

Based on several reports, rise of the anti-inflammatory cytokines and a decline in the pro-inflammatory cytokines levels happen following administration of glucocorticoids [67] furthermore, HPA regulation can be affected by pro-inflammatory cytokines, by the mean of GR counter-regulation [68]. MDD patients have been found to have higher levels of IL-6 and TNF- $\alpha$ [8] [69].

TNF- $\alpha$ as a major pro-inflammatory cytokine could prevent neurogenesis and; It has two receptor sub-types: (TNFR)-1 and (TNFR)-2. Previous evidence has shown that (TNFR)-1 could have a negative effect on the neurogenesis of adult's hippocampus. On the other hand, TNFR-2 has been reported to have a positive impact on the neurogenesis process. IL-1B level is correlated with brain neurogenesis including the hippocampal site [69]-[75]. Elevation in levels of IL-6, IL-7, IL-8, IL-10, IFN- $\alpha$ and G-CSF have been demonstrated in recent evidences [28].

\section{Cytokine Effects on the Monoamines}

\subsection{Serotonin (5-HT)}

Among all approaches in neurotransmitter process associated with depression, serotonin (5-hydroxytryptamine, 5-HT) is known to be the most investigated neurotransmitter. SSRIs are the most commonly prescribed drugs for depression [76] [77].

In the case of depression disorders, the altered aspects of serotonin system are presented as a modification in turnover of serotonin, related receptors, and the transporter binding [78]-[83].

An acute increase in serotonin level resulted from administration of inflammatory cytokines by enhancement of 5-hydroxyindoleacetic acid (5-HIAA) or 5-HIAA/5-HT ratios, in the cerebral cortex and the nucleus accumbency [84] [85] (Figure 1).

Furthermore, changes in 5-HT turnover occur concurrently with the later and more persistent depressive-like behaviors [86] [87].

During the IFN- $\alpha$ treatment, lower 5-HT concentration in the plasma and higher levels of circulating TNF- $\alpha$ were correlated with somatic symptoms in the depression 
[88]. Expressions of 5-HT1A receptors have been reported to increase during the administration of IFN- $\alpha$ [89]. "The relationship between the 5-HTTLPR and IFN- $\alpha$-induced depression was observed to depend on a functional polymorphism in the IL-6 promoter [90]." Besides, there is a positive association between the functional effects of 5 -HT and the increase in the level of IL-6. Furthermore, evidence shows that expression and function of 5-HTT is elevated as a response to IL-6 cytokine [91] [92] [93] [94].

Based on studies performed around the cytokine-induced depression therapeutic strategies, the role of 5-HT has been assessed, although SSRIs are useful for anxiety, depressed mood, and cognition therapy associated with cytokine-induced depression but not efficacious in fatigue and neurovegetative symptoms [95] [96] [97].

\subsection{Dopamine (DA) and Norepinephrine (NE)}

The main residual symptom, that occurs after SSRI treatment is fatigue. Fatigue is the underlying symptom of cytokine-induced depression. In the patients suffering from both idiopathic major depression and IFN-induced depression, the activity of basal ganglia has been modified [98] [99] [100] [101]. Evidence shows that peripheral cytokines influence the function of basal ganglia, leading to many inflammatory processes, thus related to fatigue-like symptoms [102] [103] [104].

DA neurotransmission, especially synthesis of DA, can be modified by cytokines and inflammatory signaling pathways, via various means [105].

Conversion of tyrosine (Tyr) to L-DOPA by an enzyme called Tyr hydroxylase is linked with DA synthesis. Phenylalanine (Phen) is a major source for Tyr. Phen hydroxylase $(\mathrm{PAH})$ converts Phen to Tyr. Tetrahydrobiopterin (BH4) is known as co-factor for both Tyr hydroxylase and PAH. NE concentration in the CSF of patients with major depressive disorder has been reported to be elevated [106] [107].

Cytokines, besides their role in Immune activation, lead to an increased activity in the locus coeruleus and elevation of NE in hippocampus and hypothalamus. Dunn et al. showed that there is a link between the increased activity of NE and the HPA axis [108] [109]. "5-HT and DA metabolites in the CSF have been found to correlate with IFN-alpha-induced depressive and fatigue symptoms, respectively [105] [110]" (Figure 1).

\section{Cytokine Effects on Neuropeptides and Growth Factors}

\subsection{Brain-Derived Neurotropic Factor (BDNF)}

Both the neuronal development and their apoptosis are controlled by inflammatory cytokines [111] [112]. The activities of the subsequent and the stress inflammatory cytokines have a relationship with neuroplasty and neurogenesis [113]. Furthermore, IFN- $\alpha$ is able to decrease proliferation of cells in hippocampus area; this process is mediated by IL-1. In the case of BDNF, IFN- $\alpha$ administration has decreased the level of systemic BDNF among human [114].

Remarkably, the link between the pre-existing low concentration of BDNF and the risk of cytokine-induced depression has been reported [115] [116] (Figure 1). 


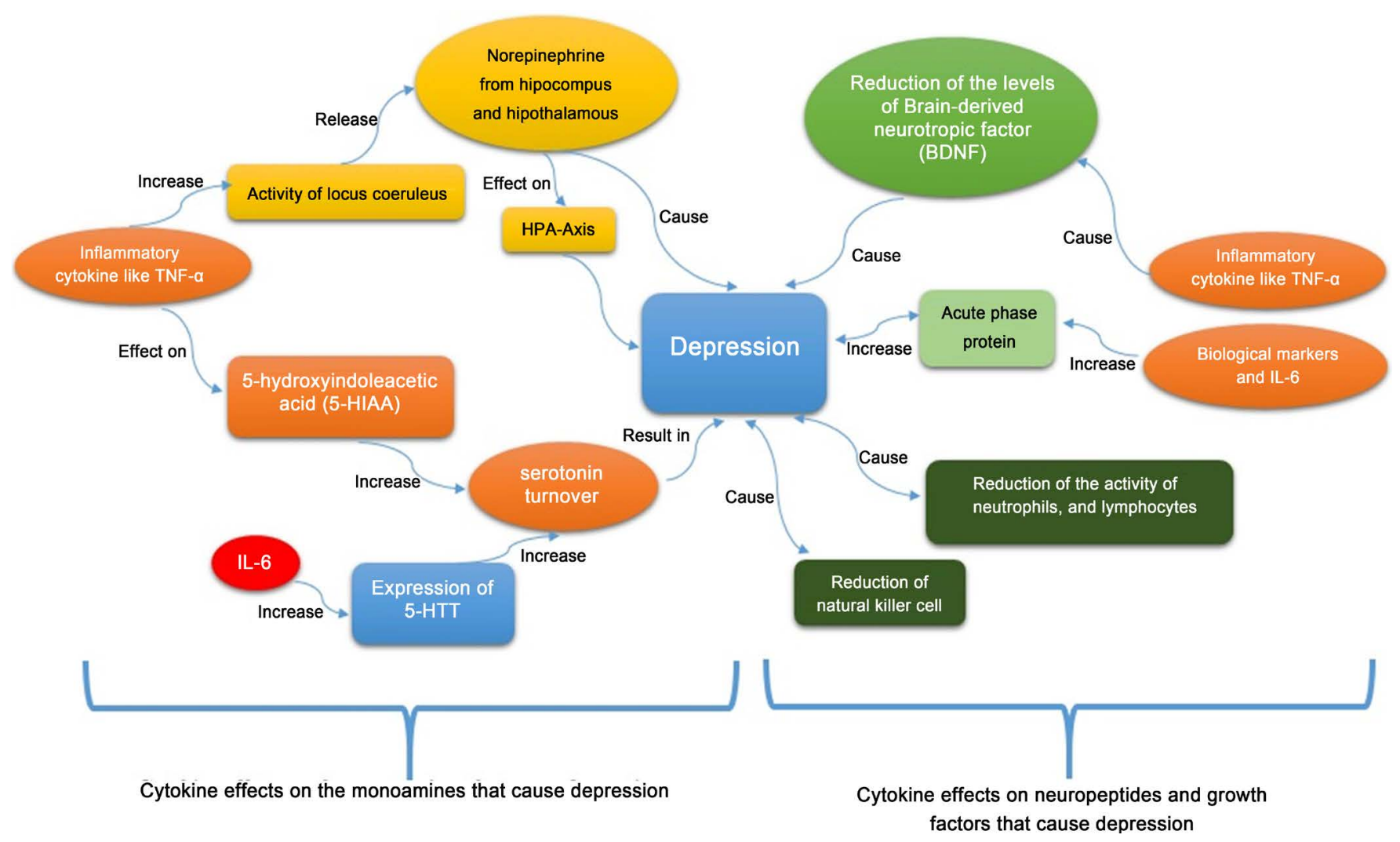

Figure 1. Cytokine effects on the monoamines, neuropeptides and growth factors that cause depression.

\subsection{Corticotrophin-Releasing Hormone (CRH)}

The roles of HPA axis and CRH have been studied in patients with major depression and cytokine-induced depression. Study performed by Arborelius and coworkers, have demonstrated increased concentration of CRH in the CSF of patients with MDD [117]. Depression is considered as a public health problem. MDD prevalence is reported up to $20 \%$ among individuals, but medically ill subjects have prevalence up to $50 \%$ [118].

Depressive patients who do not respond to antidepressant therapy have been shown to have higher levels of inflammatory cytokines and CRH in the circulation, compared with patients who are not resistant to this therapeutic procedure [119] (Figure 1).

Two studies carried out in 2011, showed that after antidepressant therapy the level of circulating BDNF has increased, but a study showed that the level of IL-6 has declined after antidepressant therapy. Additionally, the individuals with a trauma experience in childhood have higher levels of inflammatory biomarkers and demonstrate higher rates of depression [120] [121].

\subsection{Acute Phase Proteins in Major Depression}

Several documents claimed that there exist a link between depression and the immune system. A study performed on the acute phase proteins in major depression, has demonstrated that levels of C4, IL-6, and C-reactive protein were significantly elevated in the patients with depressive disorder [122]. Evidence suggests that the level of acute 
phase proteins change during depression. Such studies found an increase in the level of a1-acid glycoprotein [123]. MDD has been correlated with activation of immune system, cellular activation, rise in positive acute phase proteins, and decline of negative acute phase proteins [124] [125] [126].

Rise in the serum levels of acute phase proteins and IL-6 were significantly documented [124] [127]. Some publications reported that complement proteins C3 and C4 were not affected, but some studies showed a raise in the level of this molecules [128] [129]. The biological marker, IL-6, has the ability to stimulate acute phase protein generation by the hepatocytes [130].

Several studies investigated the relationship between immunity and clinical depression, reported a reduced level of natural killer cells and reduced activity of neutrophils lymphocytes [125] [131]-[136]. Other studies have reported an increase in the level of acute phase proteins, C3, C4, immunoglobulin M and cytokines [123] [137] [138] [139].

Enhancement of acute phase proteins, complement proteins, and IL-6 could be defined as a link for the association of major depression and immune response activation [122] (Figure 1).

\section{Conclusions}

While positive and negative findings of elevated cytokines have been outlined above, there seems to be a relation between levels of pro-inflammatory cytokines such as TNF- $\alpha$ and IL- 6 in the patients suffering from a major depressive disorder. In the case of acute phase proteins, there are some reports on the elevation of C4 and CRP levels in the MDD cases.

However, many clinical studies perform to evaluate the relation of inflammatory factors and depression but most of them are cross-sectional studies and therefore answering the question about whether inflammatory markers are one of the causes of depression or the depression increases these factors is unclear for this reason; observational studies like cohort should be necessary to determine exact effects of cytokines on happening of depression. Even though, various research on cytokines reported a higher concentration of IL-1B, IL-5, IL-15, IL-7, IL-8, IL-4, IL-10, G-CSF, MIP-1a, IFN-y, MCP, GM-CSF and IL-1a, most of the reviewed studies showed that TNF- $\alpha$ and IL-6 were the cytokines which showed a significant raise in concentration.

\section{References}

[1] Schiepers, O.J., Wichers, M.C. and Maes, M. (2005) Cytokines and Major Depression. Progress in Neuro-Psychopharmacology and Biological Psychiatry, 29, 201-217. https://doi.org/10.1016/j.pnpbp.2004.11.003

[2] Tajfard, M., Ghayour-Mobarhan, M., Rahimi, H.R., Mouhebati, M., Esmaeily, H., Ferns, G.A., et al. (2014) Anxiety, Depression and Coronary Artery Disease among Patients Undergoing Angiography in Ghaem Hospital, Mashhad, Iran. Health, 6, 1108-1115.

[3] Eyre, H., Stuart, M. and Baune, B. (2014) A Phase-Specific Neuroimmune Model of Clinical Depression. Progress in Neuro-Psychopharmacology and Biological Psychiatry, 54, 265274. https://doi.org/10.1016/j.pnpbp.2014.06.011 
[4] Simon, N., McNamara, K., Chow, C., Maser, R., Papakostas, G., Pollack, M., et al. (2008) A Detailed Examination of Cytokine Abnormalities in Major Depressive Disorder. European Neuropsychopharmacology, 18, 230-233. https://doi.org/10.1016/j.euroneuro.2007.06.004

[5] Kim, Y.-K., Na, K.-S., Myint, A.-M. and Leonard, B.E. (2015) The Role of Pro-Inflammatory Cytokines in Neuroinflammation, Neurogenesis and the Neuroendocrine System in Major depression. Progress in Neuro-Psychopharmacology and Biological Psychiatry, 64, 277-284. https://doi.org/10.1016/j.pnpbp.2015.06.008

[6] Felger, J.C. and Lotrich, F.E. (2013) Inflammatory Cytokines in Depression: Neurobiological Mechanisms and Therapeutic Implications. Neuroscience, 246, 199-229. https://doi.org/10.1016/j.neuroscience.2013.04.060

[7] Dantzer, R., O'Connor, J.C., Freund, G.G., Johnson, R.W. and Kelley, K.W. (2008) From Inflammation to Sickness and Depression: When the Immune System Subjugates the Brain. Nature Reviews Neuroscience, 9, 46-56. https://doi.org/10.1038/nrn2297

[8] Dowlati, Y., Herrmann, N., Swardfager, W., Liu, H., Sham, L., Reim, E.K., et al. (2010) A Meta-Analysis of Cytokines in Major Depression. Biological Psychiatry, 67, 446-457.

https://doi.org/10.1016/j.biopsych.2009.09.033

[9] Ader, R., Cohen, N. and Felten, D. (1995) Psychoneuroimmunology: Interactions between the Nervous System and the Immune System. The Lancet, 345, 99-103. https://doi.org/10.1016/S0140-6736(95)90066-7

[10] Berkenbosch, F., Van Oers, J., Del Rey, A., Tilders, F. and Besedovsky, H. (1987) Corticotropin-Releasing Factor-Producing Neurons in the Rat Activated by Interleukin-1. Science, 238, 524-526. https://doi.org/10.1126/science.2443979

[11] Raison, C.L., Borisov, A.S., Majer, M., Drake, D.F., Pagnoni, G., Woolwine, B.J., et al. (2009) Activation of Central Nervous System Inflammatory Pathways by Interferon-Alpha: Relationship to Monoamines and Depression. Biological Psychiatry, 65, 296-303. https://doi.org/10.1016/j.biopsych.2008.08.010

[12] Tajfard, M., GhayourMobarhan, M., Rahimi, H.R., Mouhebati, M., Esmaeily, H., Ferns, G.A., et al. (2014) Anxiety, Depression, Coronary Artery Disease and Diabetes Mellitus: An Association Study in Ghaem Hospital, Iran. Iranian Red Crescent Medical Journal, 16, e14589. https://doi.org/10.5812/ircmj. 14589

[13] Heim, C., Owens, M.J., Plotsky, P.M. and Nemeroff, C.B. (1997) Persistent Changes in Corticotropin-Releasing Factor Systems Due to Early Life Stress: Relationship to the Pathophysiology of Major Depression and Post-Traumatic Stress Disorder. Psychopharmacology Bulletin, 33, 185-192.

[14] Charney, D.S. (1998) Monamine Dysfunction and the Pathophysiology and Treatment of Depression. Journal of Clinical Psychiatry, 59, 11-14.

[15] Berman, R.M., Cappiello, A., Anand, A., Oren, D.A., Heninger, G.R., Charney, D.S., et al. (2000) Antidepressant Effects of Ketamine in Depressed Patients. Biological Psychiatry, 47, 351-354. https://doi.org/10.1016/S0006-3223(99)00230-9

[16] Pariante, C.M. and Miller, A.H. (2001) Glucocorticoid Receptors in Major Depression: Relevance to Pathophysiology and Treatment. Biological Psychiatry, 49, 391-404. https://doi.org/10.1016/S0006-3223(00)01088-X

[17] Duman, R.S. and Monteggia, L.M. (2006) A Neurotrophic Model for Stress-Related Mood Disorders. Biological Psychiatry, 59, 1116-1127. https://doi.org/10.1016/j.biopsych.2006.02.013

[18] McAfoose, J. and Baune, B. (2009) Evidence for a Cytokine Model of Cognitive Function. Neuroscience \& Biobehavioral Reviews, 33, 355-366. 
https://doi.org/10.1016/j.neubiorev.2008.10.005

[19] Miller, A.H., Maletic, V. and Raison, C.L. (2009) Inflammation and Its Discontents: The Role of Cytokines in the Pathophysiology of Major Depression. Biological Psychiatry, 65, 732-741. https://doi.org/10.1016/j.biopsych.2008.11.029

[20] Eyre, H. and Baune, B.T. (2012) Neuroplastic Changes in Depression: A Role for the Immune System. Psychoneuroendocrinology, 37, 1397-1416. https://doi.org/10.1016/j.psyneuen.2012.03.019

[21] Leonard, B. and Maes, M. (2012) Mechanistic Explanations How Cell-Mediated Immune Activation, Inflammation and Oxidative and Nitrosative Stress Pathways and Their Sequels and Concomitants Play a Role in the Pathophysiology of Unipolar Depression. Neuroscience \& Biobehavioral Reviews, 36, 764-785.

https://doi.org/10.1016/j.neubiorev.2011.12.005

[22] Moylan, S., Maes, M., Wray, N. and Berk, M. (2013) The Neuroprogressive Nature of Major Depressive Disorder: Pathways to Disease Evolution and Resistance, and Therapeutic Implications. Molecular Psychiatry, 18, 595-606. https://doi.org/10.1038/mp.2012.33

[23] Tajfard, M., Latiff, L.A., Rahimi, H.R., Mouhebati, M., Esmaeily, H., Taghipour, A., et al. (2014) Serum Inflammatory Cytokines and Depression in Coronary Artery Disease. Iranian Red Crescent Medical Journal, 16, e17111. https://doi.org/10.5812/ircmj.17111

[24] Anisman, H., Merali, Z., Poulter, M.O. and Hayley, S. (2005) Cytokines as a Precipitant of Depressive Illness: Animal and Human Studies. Current Pharmaceutical Design, 11, $963-$ 972. https://doi.org/10.2174/1381612053381701

[25] Hiles, S.A., Baker, A.L., de Malmanche, T. and Attia, J. (2012) A Meta-Analysis of Differences in IL-6 and IL-10 between People with and without Depression: Exploring the Causes of Heterogeneity. Brain, Behavior, and Immunity, 26, 1180-1188.

https://doi.org/10.1016/j.bbi.2012.06.001

[26] Vogelzangs, N., Duivis, H.E., Beekman, A.T., Kluft, C., Neuteboom, J., Hoogendijk, W., et al. (2012) Association of Depressive Disorders, Depression Characteristics and Antidepressant Medication with Inflammation. Translational Psychiatry, 2, e79.

https://doi.org/10.1038/tp.2012.8

[27] Maes, M., Mihaylova, I., Kubera, M. and Ringel, K. (2012) Activation of Cell-Mediated Immunity in Depression: Association with Inflammation, Melancholia, Clinical Staging and the Fatigue and Somatic Symptom Cluster of Depression. Progress in Neuro-Psychopharmacology and Biological Psychiatry, 36, 169-175.

https://doi.org/10.1016/j.pnpbp.2011.09.006

[28] Dahl, J., Ormstad, H., Aass, H.C.D., Malt, U.F., Bendz, L.T., Sandvik, L., et al. (2014) The Plasma Levels of Various Cytokines Are Increased during Ongoing Depression and Are Reduced to Normal Levels after Recovery. Psychoneuroendocrinology, 45, 77-86. https://doi.org/10.1016/j.psyneuen.2014.03.019

[29] Maes, M., Lambrechts, J., Bosmans, E., Jacobs, J., Suy, E., Vandervorst, C., et al. (1992) Evidence for a Systemic Immune Activation during Depression: Results of Leukocyte Enumeration by Flow Cytometry in Conjunction with Monoclonal Antibody Staining. Psychological Medicine, 22, 45-53. https://doi.org/10.1017/S0033291700032712

[30] Maes, M. (1999) Major Depression and Activation of the Inflammatory Response System. In: Dantzer, R., Wollman, E.E. and Yirmiya, R., Eds., Cytokines, Stress, and Depression, Springer, Berlin, 25-46. https://doi.org/10.1007/978-0-585-37970-8 2

[31] Sluzewska, A. (1999) Indicators of Immune Activation in Depressed Patients. In: Dantzer, R., Wollman, E.E. and Yirmiya, R., Eds., Cytokines, Stress, and Depression, Springer, Berlin, 59-73. https://doi.org/10.1007/978-0-585-37970-8 4 
[32] Levine, J., Barak, Y., Chengappa, K., Rapoport, A., Rebey, M. and Barak, V. (1999) Cerebrospinal Cytokine Levels in Patients with Acute Depression. Neuropsychobiology, 40, 171-176. https://doi.org/10.1159/000026615

[33] Lindqvist, D., Janelidze, S., Hagell, P., Erhardt, S., Samuelsson, M., Minthon, L., et al. (2009) Interleukin-6 Is Elevated in the Cerebrospinal Fluid of Suicide Attempters and Related to Symptom Severity. Biological Psychiatry, 66, 287-292.

https://doi.org/10.1016/j.biopsych.2009.01.030

[34] Martinez, J.M., Garakani, A., Yehuda, R. and Gorman, J.M. (2012) Proinflammatory and "Resiliency" Proteins in the CSF of Patients with Major Depression. Depression and Anxiety, 29, 32-38. https://doi.org/10.1002/da.20876

[35] Linnoila, M., Whorton, A.R., Rubinow, D.R., Cowdry, R.W., Ninan, P.T. and Waters, R.N. (1983) CSF Prostaglandin Levels in Depressed and Schizophrenic Patients. Archives of General Psychiatry, 40, 405-406. https://doi.org/10.1001/archpsyc.1983.01790040059008

[36] Calabrese, J.R., Skwerer, R.G., Barna, B., Gulledge, A.D., Valenzuela, R., Butkus, A., et al. (1986) Depression, Immunocompetence, and Prostaglandins of the E Series. Psychiatry Research, 17, 41-47. https://doi.org/10.1016/0165-1781(86)90040-5

[37] Ohishi, K., Ueno, R., Nishino, S., Sakai, T. and Hayaishi, O. (1988) Increased Level of Salivary Prostaglandins in Patients with Major Depression. Biological Psychiatry, 23, 326-334. https://doi.org/10.1016/0006-3223(88)90283-1

[38] Nishino, S., Ueno, R., Ohishi, K., Sakai, T. and Hayaishi, O. (1989) Salivary Prostaglandin Concentrations: Possible State Indicators for Major Depression. The American Journal of Psychiatry, 146, 365-368. https://doi.org/10.1176/ajp.146.3.365

[39] Capuron, L., Gumnick, J.F., Musselman, D.L., Lawson, D.H., Reemsnyder, A., Nemeroff, C.B., et al. (2002) Neurobehavioral Effects of Interferon- $\alpha$ in Cancer Patients: Phenomenology and Paroxetine Responsiveness of Symptom Dimensions. Neuropsychopharmacology, 26, 643-652. https://doi.org/10.1016/S0893-133X(01)00407-9

[40] Maddock, C., Landau, S., Barry, K., Maulayah, P., Hotopf, M., Cleare, A., et al. (2005) Psychopathological Symptoms during Interferon- $\alpha$ and Ribavirin Treatment: Effects on Virologic Response. Molecular Psychiatry, 10, 332-333. https://doi.org/10.1038/sj.mp.4001634

[41] Raison, C.L., Borisov, A.S., Broadwell, S.D., Capuron, L., Woolwine, B.J., Jacobson, I.M., et al. (2005) Depression during Pegylated Interferon-Alpha plus Ribavirin Therapy: Prevalence and Prediction. Journal of Clinical Psychiatry, 66, 41-48.

https://doi.org/10.4088/JCP.v66n0106

[42] Lotrich, F.E. (2009) Major Depression during Interferon- $\alpha$ Treatment: Vulnerability and Prevention. Dialogues in Clinical Neuroscience, 11, 417-425.

[43] Charo, I.F. and Ransohoff, R.M. (2006) The Many Roles of Chemokines and Chemokine Receptors in Inflammation. The New England Journal of Medicine, 354, 610-621. https://doi.org/10.1056/NEJMra052723

[44] Yirmiya, R. and Goshen, I. (2011) Immune Modulation of Learning, Memory, Neural Plasticity and Neurogenesis. Brain, Behavior, and Immunity, 25, 181-213. https://doi.org/10.1016/j.bbi.2010.10.015

[45] Haroon, E., Raison, C.L. and Miller, A.H. (2012) Psychoneuroimmunology Meets Neuropsychopharmacology: Translational Implications of the Impact of Inflammation on Behavior. Neuropsychopharmacology, 37, 137-162. https://doi.org/10.1038/npp.2011.205

[46] Yirmiya, R., Weidenfeld, J., Pollak, Y., Morag, M., Morag, A., Avitsur, R., et al. (1999) Cytokines, "Depression Due to a General Medical Condition," and Antidepressant Drugs. In: Dantzer, R., Wollman, E.E. and Yirmiya, R., Eds., Cytokines, Stress, and Depression, 
Springer, Berlin, 283-316. https://doi.org/10.1007/978-0-585-37970-8 16

[47] Yirmiya, R., Pollak, Y., Morag, M., Reichenberg, A., Barak, O., Avitsur, R., et al. (2000) Illness, Cytokines, and Depression. Annals of the New York Academy of Sciences, 917, 478487. https://doi.org/10.1111/j.1749-6632.2000.tb05412.x

[48] Sheng, W., Zong, Y., Mohammad, A., et al. (2011) Pro-inflammatory Cytokines and Lipopolysaccharide Induce Changes in Cell Morphology, and Upregulation of ERK1/2, iNOS and sPLA2-IIA Expression in Astrocytes and Microglia. Journal of Neuroinflammation, 8, 121. https://doi.org/10.1186/1742-2094-8-121

[49] Muñoz-Fernández, M.A. and Fresno, M. (1998) The Role of Tumour Necrosis Factor, Interleukin 6, Interferon- $\gamma$ and Inducible Nitric Oxide Synthase in the Development and Pathology of the Nervous System. Progress in Neurobiology, 56, 307-340.

https://doi.org/10.1016/S0301-0082(98)00045-8

[50] Capuron, L., Ravaud, A., Miller, A.H. and Dantzer, R. (2004) Baseline Mood and Psychosocial Characteristics of Patients Developing Depressive Symptoms during Interleukin-2 and/or Interferon-Alpha Cancer Therapy. Brain, Behavior, and Immunity, 18, 205-213. https://doi.org/10.1016/j.bbi.2003.11.004

[51] Capuron, L., Fornwalt, F.B., Knight, B.T., Harvey, P.D., Ninan, P.T. and Miller, A.H. (2009) Does Cytokine-Induced Depression Differ from Idiopathic Major Depression in Medically Healthy Individuals? Journal of Affective Disorders, 119, 181-185. https://doi.org/10.1016/j.jad.2009.02.017

[52] Schiepers, O.J., Wichers, M.C. and Maes, M. (2005) Cytokines and Major Depression. Progress in Neuro-Psychopharmacology \& Biological Psychiatry, 29, 201-217. https://doi.org/10.1016/j.pnpbp.2004.11.003

[53] Marques-Deak, A.H., Neto, F.L., Dominguez, W.V., et al. (2007) Cytokine Profiles in Women with Different Subtypes of Major Depressive Disorder. Journal of Psychiatric Research, 41, 152-159. https://doi.org/10.1016/j.jpsychires.2005.11.003

[54] Tsao, C.W., Lin, Y.S., Chen, C.C., Bai, C.H. and Wu, S.R. (2006) Cytokines and Serotonin Transporter in Patients with Major Depression. Progress in Neuro-Psychopharmacology \& Biological Psychiatry, 30, 899-905. https://doi.org/10.1016/j.pnpbp.2006.01.029

[55] Anisman, H., Ravindran, A.V., Griffiths, J. and Merali, Z. (1999) Endocrine and Cytokine Correlates of Major Depression and Dysthymia with Typical or Atypical Features. Molecular Psychiatry, 4, 182-188. https://doi.org/10.1038/sj.mp.4000436

[56] Maes, M., Lin, A.H., Delmeire, L., et al. (1999) Elevated Serum Interleukin-6 (IL-6) and IL-6 Receptor Concentrations in Posttraumatic Stress Disorder Following Accidental ManMade Traumatic Events. Biological Psychiatry, 45, 833-839. https://doi.org/10.1016/S0006-3223(98)00131-0

[57] Rajagopalan, S., Brook, R., Rubenfire, M., Pitt, E., Young, E. and Pitt, B. (2001) Abnormal Brachial Artery Flow-Mediated Vasodilation in Young Adults with Major Depression. The American Journal of Cardiology, 88, 196-198. https://doi.org/10.1016/S0002-9149(01)01623-X

[58] Pace, T.W., Mletzko, T.C., Alagbe, O., et al. (2006) Increased Stress-Induced Inflammatory Responses in Male Patients with Major Depression and Increased Early Life Stress. American Journal of Psychiatry, 163, 1630-1633. https://doi.org/10.1176/ajp.2006.163.9.1630

[59] Kaestner, F., Hettich, M., Peters, M., et al. (2005) Different Activation Patterns of Proinflammatory Cytokines in Melancholic and Non-Melancholic Major Depression Are Associated with HPA Axis Activity. Journal of Affective Disorders, 87, 305-311. https://doi.org/10.1016/j.jad.2005.03.012 
[60] Suarez, E.C., Krishnan, R.R. and Lewis, J.G. (2003) The Relation of Severity of Depressive Symptoms to Monocyte-Associated Proinflammatory Cytokines and Chemokines in Apparently Healthy Men. Psychosomatic Medicine, 65, 362-368. https://doi.org/10.1097/01.PSY.0000035719.79068.2B

[61] Schlatter, J., Ortuno, F. and Cervera-Enguix, S. (2001) Differences in Interleukins' Patterns between Dysthymia and Major Depression. European Psychiatry, 16, 317-319. https://doi.org/10.1016/S0924-9338(01)00585-5

[62] Smith, R. (1991) The Macrophage Theory of Depression. Medical Hypotheses, 35, 298-306. https://doi.org/10.1016/0306-9877(91)90272-Z

[63] Kim, Y.K. and Maes, M. (2003) The Role of the Cytokine Network in Psychological Stress. Acta Neuropsychiatrica, 15, 148-155. https://doi.org/10.1034/j.1601-5215.2003.00026.x

[64] Kim, Y.-K., Na, K.-S., Shin, K.-H., Jung, H.-Y., Choi, S.-H. and Kim, J.-B. (2007) Cytokine Imbalance in the Pathophysiology of Major Depressive Disorder. Progress in Neuro-Psychopharmacology and Biological Psychiatry, 31, 1044-1053.

https://doi.org/10.1016/j.pnpbp.2007.03.004

[65] Zellweger, M.J., Osterwalder, R.H., Langewitz, W. and Pfisterer, M.E. (2004) Coronary Artery Disease and Depression. European Heart Journal, 25, 3-9. https://doi.org/10.1016/j.ehj.2003.09.009

[66] Bonaccorso, S., Marino, V., Biondi, M., Grimaldi, F., Ippoliti, F. and Maes, M. (2002) Depression Induced by Treatment with Interferon-Alpha in Patients Affected by Hepatitis C Virus. Journal of Affective Disorders, 72, 237-241. https://doi.org/10.1016/S0165-0327(02)00264-1

[67] Blotta, M.H., DeKruyff, R.H. and Umetsu, D.T. (1997) Corticosteroids Inhibit IL-12 Production in Human Monocytes and Enhance Their Capacity to Induce IL-4 Synthesis in CD4+ Lymphocytes. The Journal of Immunology, 158, 5589-5595.

[68] Pace, T.W., Hu, F. and Miller, A.H. (2007) Cytokine-Effects on Glucocorticoid Receptor Function: Relevance to Glucocorticoid Resistance and the Pathophysiology and Treatment of Major Depression. Brain, Behavior, and Immunity, 21, 9-19. https://doi.org/10.1016/j.bbi.2006.08.009

[69] Monje, M.L., Toda, H. and Palmer, T.D. (2003) Inflammatory Blockade Restores Adult Hippocampal Neurogenesis. Science, 302, 1760-1765. https://doi.org/10.1126/science.1088417

[70] Keohane, A., Ryan, S., Maloney, E., Sullivan, A.M. and Nolan, Y.M. (2010) Tumour Necrosis Factor- $\alpha$ Impairs Neuronal Differentiation but Not Proliferation of Hippocampal Neural Precursor Cells: Role of Hes1. Molecular and Cellular Neuroscience, 43, 127-135. https://doi.org/10.1016/j.mcn.2009.10.003

[71] Koo, J.W. and Duman, R.S. (2008) IL-1Beta Is an Essential Mediator of the Antineurogenic and Anhedonic Effects of Stress. Proceedings of the National Academy of Sciences of the United States of America, 105, 751-756. https://doi.org/10.1073/pnas.0708092105

[72] Kuzumaki, N., Ikegami, D., Imai, S., et al. (2010) Enhanced IL-1 $\beta$ Production in Response to the Activation of Hippocampal Glial Cells Impairs Neurogenesis in Aged Mice. Synapse, 64, 721-728. https://doi.org/10.1002/syn.20800

[73] Ben-Hur, T., Ben-Menachem, O., Furer, V., Einstein, O., Mizrachi-Kol, R. and Grigoriadis, N. (2003) Effects of Proinflammatory Cytokines on the Growth, Fate, and Motility of Multipotential Neural Precursor Cells. Molecular and Cellular Neuroscience, 24, 623-631. https://doi.org/10.1016/S1044-7431(03)00218-5

[74] Dybedal, I., Bryder, D., Fossum, A., Rusten, L.S. and Jacobsen, S. (2001) Tumor Necrosis 
Factor (TNF)-Mediated Activation of the p55 TNF Receptor Negatively Regulates Maintenance of Cycling Reconstituting Human Hematopoietic Stem Cells. Blood, 98, 1782-1791. https://doi.org/10.1182/blood.V98.6.1782

[75] Iosif, R.E., Ekdahl, C.T., Ahlenius, H., et al. (2006) Tumor Necrosis Factor Receptor 1 Is a Negative Regulator of Progenitor Proliferation in Adult Hippocampal Neurogenesis. The Journal of Neuroscience, 26, 9703-9712. https://doi.org/10.1523/JNEUROSCI.2723-06.2006

[76] Masand, P.S. and Gupta, S. (1999) Selective Serotonin-Reuptake Inhibitors: An Update. Harvard Review of Psychiatry, 7, 69-84. https://doi.org/10.3109/hrp.7.2.69

[77] Vaswani, M., Linda, F.K. and Ramesh, S. (2003) Role of Selective Serotonin Reuptake Inhibitors in Psychiatric Disorders: A Comprehensive Review. Progress in Neuro-Psychopharmacology and Biological Psychiatry, 27, 85-102. https://doi.org/10.1016/S0278-5846(02)00338-X

[78] Perry, E.K., Marshall, E., Blessed, G., Tomlinson, B. and Perry, R. (1983) Decreased Imipramine Binding in the Brains of Patients with Depressive Illness. The British Journal of Psychiatry, 142, 188-192. https://doi.org/10.1192/bjp.142.2.188

[79] Arango, V., Underwood, M.D., Gubbi, A.V. and Mann, J. (1995) Localized Alterations in Pre-and Postsynaptic Serotonin Binding Sites in the Ventrolateral Prefrontal Cortex of Suicide Victims. Brain Research, 688, 121-133. https://doi.org/10.1016/0006-8993(95)00523-S

[80] Arango, V., Underwood, M.D., Boldrini, M., Tamir, H., et al. (2001) Serotonin 1A Receptors, Serotonin Transporter Binding and Serotonin Transporter mRNA Expression in the Brainstem of Depressed Suicide Victims. Neuropsychopharmacology, 25, 892-903. https://doi.org/10.1016/S0893-133X(01)00310-4

[81] Malison, R.T., Price, L.H., Berman, R., et al. (1998) Reduced Brain Serotonin Transporter Availability in Major Depression as Measured by $\left.{ }^{123} \mathrm{I}\right]-2 \beta$-carbomethoxy-3 $\beta$-(4-Iodophenyl) Tropane and Single Photon Emission Computed Tomography. Biological Psychiatry, 44, 1090-1098. https://doi.org/10.1016/S0006-3223(98)00272-8

[82] Mann, J.J., Huang, Y., Underwood, M.D., et al. (2000) A Serotonin Transporter Gene Promoter Polymorphism (5-HTTLPR) and Prefrontal Cortical Binding in Major Depression and Suicide. Archives of General Psychiatry, 57, 729-738.

https://doi.org/10.1001/archpsyc.57.8.729

[83] Willeit, M., Praschak-Rieder, N., Neumeister, A., et al. (2000) [123I]- $\beta$-CIT SPECT Imaging Shows Reduced Brain Serotonin Transporter Availability in Drug-Free Depressed Patients with Seasonal Affective Disorder. Biological Psychiatry, 47, 482-489. https://doi.org/10.1016/S0006-3223(99)00293-0

[84] Song, C., Merali, Z. and Anisman, H. (1999) Variations of Nucleus Accumbens Dopamine and Serotonin Following Systemic Interleukin-1, Interleukin-2 or Interleukin-6 Treatment. Neuroscience, 88, 823-836. https://doi.org/10.1016/S0306-4522(98)00271-1

[85] De La Garza, R. and Asnis, G.M. (2003) The Non-Steroidal Anti-Inflammatory Drug Diclofenac Sodium Attenuates IFN- $\alpha$ Induced Alterations to Monoamine Turnover in Prefrontal Cortex and Hippocampus. Brain Research, 977, 70-79.

https://doi.org/10.1016/S0006-8993(03)02757-4

[86] Frenois, F., Moreau, M., O’Connor, J., et al. (2007) Lipopolysaccharide Induces Delayed FosB/DeltaFosB Immunostaining within the Mouse Extended Amygdala, Hippocampus and Hypothalamus, That Parallel the Expression of Depressive-Like Behavior. Psychoneuroendocrinology, 32, 516-531. https://doi.org/10.1016/j.psyneuen.2007.03.005

[87] O’connor, J., Lawson, M., Andre, C., Moreau, M., Lestage, J., Castanon, N., et al. (2009) Lipopolysaccharide-Induced Depressive-Like Behavior Is Mediated by Indoleamine 2,3Dioxygenase Activation in Mice. Molecular Psychiatry, 14, 511-522. 
https://doi.org/10.1038/sj.mp.4002148

[88] Loftis, J.M., Patterson, A.L., Wilhelm, C.J., McNett, H., Morasco, B.J., Huckans, M., et al. (2013) Vulnerability to Somatic Symptoms of Depression during Interferon-Alpha Therapy for Hepatitis C: A 16-Week Prospective Study. Journal of Psychosomatic Research, 74, 5763. https://doi.org/10.1016/j.jpsychores.2012.10.012

[89] Abe, S., Hori, T., Suzuki, T., Baba, A., Shiraishi, H. and Yamamoto, T. (1999) Effects of Chronic Administration of Interferon Alpha A/D on Serotonergic Receptors in Rat Brain. Neurochemical Research, 24, 359-363. https://doi.org/10.1023/A:1020929415443

[90] Bull, S.J., Huezo-Diaz, P., Binder, E.B., Cubells, J.F., et al. (2009) Functional Polymorphisms in the Interleukin-6 and Serotonin Transporter Genes, and Depression and Fatigue Induced by Interferon-Alpha and Ribavirin Treatment. Molecular Psychiatry, 14, 1095-1104. https://doi.org/10.1038/mp.2008.48

[91] Morikawa, O., Sakai, N., Obara, H. and Saito, N. (1998) Effects of Interferon-Alpha, Interferon-Gamma and cAMP on the Transcriptional Regulation of the Serotonin Transporter. European Journal of Pharmacology, 349, 317-324. https://doi.org/10.1016/S0014-2999(98)00187-3

[92] Mossner, R., Heils, A., Stober, G., Okladnova, O., Daniel, S. and Lesch, K.P. (1998) Enhancement of Serotonin Transporter Function by Tumor Necrosis Factor Alpha but Not by Interleukin-6. Neurochemistry International, 33, 251-254. https://doi.org/10.1016/S0197-0186(98)00026-6

[93] Sakai, K., Hasegawa, C., Okura, M., Morikawa, O., et al. (2003) Novel Variants of Murine Serotonin Transporter mRNA and the Promoter Activity of Its Upstream Site. Neuroscience Letters, 342, 175-178. https://doi.org/10.1016/S0304-3940(03)00292-1

[94] Tsao, C.W., Lin, Y.S., Cheng, J.T., Lin, C.F., Wu, H.T., et al. (2008) Interferon-Alpha-Induced Serotonin Uptake in Jurkat T Cells via Mitogen-Activated Protein Kinase and Transcriptional Regulation of the Serotonin Transporter. Journal of Psychopharmacology, 22, 753-760. https://doi.org/10.1177/0269881107082951

[95] Raison, C.L., Demetrashvili, M., Capuron, L. and Miller, A.H. (2005) Neuropsychiatric Adverse Effects of Interferon-Alpha: Recognition and Management. CNS Drugs, 19, 105-123. https://doi.org/10.2165/00023210-200519020-00002

[96] McNutt, M.D., Liu, S., Manatunga, A., Royster, E.B., Raison, C.L., Woolwine, B.J., et al. (2012) Neurobehavioral Effects of Interferon-Alpha in Patients with Hepatitis-C: Symptom Dimensions and Responsiveness to Paroxetine. Neuropsychopharmacology, 37, 1444-1454. https://doi.org/10.1038/npp.2011.330

[97] Capuron, L., Gumnick, J.F., Musselman, D.L., Lawson, D.H., et al. (2002) Neurobehavioral Effects of Interferon-Alpha in Cancer Patients: Phenomenology and Paroxetine Responsiveness of Symptom Dimensions. Neuropsychopharmacology, 26, 643-652. https://doi.org/10.1016/S0893-133X(01)00407-9

[98] Epstein, J., Pan, H., Kocsis, J.H., Yang, Y., Butler, T., Chusid, J., et al. (2006) Lack of Ventral striatal Response to Positive Stimuli in Depressed versus Normal Subjects. American Journal of Psychiatry, 163, 1784-1790. https://doi.org/10.1176/ajp.2006.163.10.1784

[99] Capuron, L., Pagnoni, G., Demetrashvili, M.F., Lawson, D.H., et al. (2007) Basal Ganglia Hypermetabolism and Symptoms of Fatigue during Interferon-Alpha Therapy. Neuropsychopharmacology, 32, 2384-2392. https://doi.org/10.1038/sj.npp.1301362

[100] Capuron, L., Pagnoni, G., Drake, D.F., Woolwine, B.J., et al. (2012) Dopaminergic Mechanisms of Reduced Basal Ganglia Responses to Hedonic Reward during Interferon Alfa Administration. Archives of General Psychiatry, 69, 1044-1053.

https://doi.org/10.1001/archgenpsychiatry.2011.2094 
[101] Furman, D.J., Hamilton, J.P. and Gotlib, I.H. (2011) Frontostriatal Functional Connectivity in Major Depressive Disorder. Biology of Mood \& Anxiety Disorders, 1, 11.

https://doi.org/10.1186/2045-5380-1-11

[102] Capuron, L., Ravaud, A. and Dantzer, R. (2001) Timing and Specificity of the Cognitive Changes Induced by Interleukin-2 and Interferon-Alpha Treatments in Cancer Patients. Psychosomatic Medicine, 63, 376-386. https://doi.org/10.1097/00006842-200105000-00007

[103] Capuron, L., Fornwalt, F.B., Knight, B.T., Harvey, P.D., Ninan, P.T. and Miller, A.H. (2009) Does Cytokine-Induced Depression Differ from Idiopathic Major Depression in Medically Healthy Individuals? Journal of Affective Disorders, 119, 181-185. https://doi.org/10.1016/j.jad.2009.02.017

[104] Majer, M., Welberg, L.A., Capuron, L., Pagnoni, G., Raison, C.L. and Miller, A.H. (2008) IFN-Alpha-Induced Motor Slowing Is Associated with Increased Depression and Fatigue in Patients with Chronic Hepatitis C. Brain, Behavior, and Immunity, 22, 870-880. https://doi.org/10.1016/j.bbi.2007.12.009

[105] Felger, J.C. and Miller, A.H. (2012) Cytokine Effects on the Basal Ganglia and Dopamine Function: The Subcortical Source of Inflammatory Malaise. Frontiers in Neuroendocrinology, 33, 315-327. https://doi.org/10.1016/j.yfrne.2012.09.003

[106] Roy, A., Linnoila, M., Karoum, F. and Pickar, D. (1986) Relative Activity of Metabolic Pathways for Norepinephrine in Endogenous Depression. Acta Psychiatrica Scandinavica, 73, 624-628. https://doi.org/10.1111/j.1600-0447.1986.tb02734.x

[107] Gudmundsson, P., Skoog, I., Waern, M., Blennow, K., Palsson, S., Rosengren, L., et al. (2007) The Relationship between Cerebrospinal Fluid Biomarkers and Depression in Elderly Women. The American Journal of Geriatric Psychiatry, 15, 832-838. https://doi.org/10.1097/JGP.0b013e3180547091

[108] Dunn, A.J., Wang, J. and Ando, T. (1999) Effects of Cytokines on Cerebral Neurotransmission. Comparison with the Effects of Stress. Advances in Experimental Medicine and Biology, 461, 117-127. https://doi.org/10.1007/978-0-585-37970-8 8

[109] Dunn, A.J., Swiergiel, A.H. and de Beaurepaire, R. (2005) Cytokines as Mediators of Depression: What Can We Learn from Animal Studies? Neuroscience and Biobehavioral Reviews, 29, 891-909. https://doi.org/10.1016/j.neubiorev.2005.03.023

[110] Raison, C.L., Borisov, A.S., Majer, M., Drake, D.F., Pagnoni, G., Woolwine, B.J., et al. (2009) Activation of Central Nervous System Inflammatory Pathways by Interferon-Alpha: Relationship to Monoamines and Depression. Biological Psychiatry, 65, 296-303. https://doi.org/10.1016/j.biopsych.2008.08.010

[111] Mehler, M.F. and Kessler, J.A. (1997) Hematolymphopoietic and Inflammatory Cytokines in Neural Development. Trends in Neurosciences, 20, 357-365. https://doi.org/10.1016/S0166-2236(96)01045-4

[112] Zhao, B. and Schwartz, J.P. (1998) Involvement of Cytokines in Normal CNS Development and Neurological Diseases: Recent Progress and Perspectives. Journal of Neuroscience Research, 52, 7-16. https://doi.org/10.1002/(SICI)1097-4547(19980401)52:1<7::AID-JNR2>3.0.CO;2-I

[113] Patel, H.C., Boutin, H. and Allan, S.M. (2003) Interleukin-1 in the Brain: Mechanisms of Action in Acute Neurodegeneration. Annals of the New York Academy of Sciences, 992, 39-47. https://doi.org/10.1111/j.1749-6632.2003.tb03136.x

[114] Kenis, G., Prickaerts, J., van Os, J., Koek, G.H., et al. (2011) Depressive Symptoms Following Interferon-Alpha Therapy: Mediated by Immune-Induced Reductions in Brain-Derived Neurotrophic Factor? The International Journal of Neuropsychopharmacology, 14, 247253. https://doi.org/10.1017/S1461145710000830 
[115] Sarchiapone, M., Carli, V., Roy, A., Iacoviello, L., et al. (2008) Association of Polymorphism (Val66Met) of Brain-Derived Neurotrophic Factor with Suicide Attempts in Depressed Patients. Neuropsychobiology, 57, 139-145. https://doi.org/10.1159/000142361

[116] Aguilera, M., Arias, B., Wichers, M., Barrantes-Vidal, N., et al. (2009) Early Adversity and 5-HTT/BDNF Genes: New Evidence of Gene-Environment Interactions on Depressive Symptoms in a General Population. Psychological Medicine, 39, 1425-1432. https://doi.org/10.1017/S0033291709005248

[117] Arborelius, L., Owens, M.J., Plotsky, P. and Nemeroff, C.B. (1999) The Role of Corticotropin-Releasing Factor in Depression and Anxiety Disorders. The Journal of Endocrinology, 160, 1-12. https://doi.org/10.1677/joe.0.1600001

[118] Blazer, D.G., Kessler, R.C., McGonagle, K.A. and Swartz, M.S. (1994) The Prevalence and Distribution of Major Depression in a National Community Sample: The National Comorbidity Survey. American Journal of Psychiatry, 151, 979-986. https://doi.org/10.1176/ajp.151.7.979

[119] Sluzewska, A., Sobieska, M. and Rybakowski, J.K. (1997) Changes in Acute-Phase Proteins during Lithium Potentiation of Antidepressants in Refractory Depression. Neuropsychobiology, 35, 123-127. https://doi.org/10.1159/000119332

[120] Danese, A., Pariante, C.M., Caspi, A., Taylor, A. and Poulton, R. (2007) Childhood Maltreatment Predicts Adult Inflammation in a Life-Course Study. Proceedings of the National Academy of Sciences of the United States of America, 104, 1319-1324. https://doi.org/10.1073/pnas.0610362104

[121] Danese, A., Moffitt, T.E., Pariante, C.M., Ambler, A., Poulton, R. and Caspi, A. (2008) Elevated Inflammation Levels in Depressed Adults with a History of Childhood Maltreatment. Archives of General Psychiatry, 65, 409-415. https://doi.org/10.1001/archpsyc.65.4.409

[122] Berk, M., Wadee, A., Kuschke, R. and O’Neill-Kerr, A. (1997) Acute Phase Proteins in Major Depression. Journal of Psychosomatic Research, 43, 529-534. https://doi.org/10.1016/S0022-3999(97)00139-6

[123] Healy, D., Calvin, J., Whitehouse, A., White, W., Wilton-Cox, H., Theodorou, A., et al. (1991) Alpha-1-Acid Glycoprotein in Major Depressive and Eating Disorders. Journal of Affective Disorders, 22, 13-20. https://doi.org/10.1016/0165-0327(91)90078-7

[124] Maes, M., Wauters, A., Neels, H., Scharpé, S., et al. (1995) Total Serum Protein and Serum Protein Fractions in Depression: Relationships to Depressive Symptoms and Glucocorticoid Activity. Journal of Affective Disorders, 34, 61-69. https://doi.org/10.1016/0165-0327(94)00106-I

[125] Maes, M. (1995) Evidence for an Immune Response in Major Depression: A Review and Hypothesis. Progress in Neuro-Psychopharmacology and Biological Psychiatry, 19, 11-38. https://doi.org/10.1016/0278-5846(94)00101-M

[126] Maes, M., Scharpe, S., Bosmans, E., Vandewoude, M., et al. (1992) Disturbances in Acute Phase Plasma Proteins during Melancholia: Additional Evidence for the Presence of an Inflammatory Process during That Illness. Progress in Neuro-Psychopharmacology and Biological Psychiatry, 16, 501-515. https://doi.org/10.1016/0278-5846(92)90056-K

[127] Maes, M., Meltzer, H.Y., Bosmans, E., Bergmans, R., Vandoolaeghe, E., Ranjan, R., et al. (1995) Increased Plasma Concentrations of Interleukin-6, Soluble Interleukin-6, Soluble Interleukin-2 and Transferrin Receptor in Major Depression. Journal of Affective Disorders, 34, 301-309. https://doi.org/10.1016/0165-0327(95)00028-L

[128] Maes, M., Bosmans, E. and Meltzer, H.Y. (1995) Immunoendocrine Aspects of Major Depression. European Archives of Psychiatry and Clinical Neuroscience, 245, 172-178. https://doi.org/10.1007/BF02193091 
[129] Elliott, G.R. and Eisdorfer, C. (1982) Stress and Human Health. Springer, New York.

[130] Herbert, T.B. and Cohen, S. (1993) Depression and Immunity: A Meta-Analytic Review. Psychological Bulletin, 113, 472-486. https://doi.org/10.1037/0033-2909.113.3.472

[131] Miller, A.H., Spencer, R.L., McEwen, B.S. and Stein, M. (1993) Depression, Adrenal Steroids, and the Immune system. Annals of Medicine, 25, 481-487. https://doi.org/10.3109/07853899309147316

[132] Kronfol, Z., Silva, J., Greden, J., Dembinski, S. and Carroll, B. (1982) Cell-Mediated Immunity in Melancholia. Psychosomatic Medicine, 44, 304.

[133] Schleifer, S.J., Keller, S.E., Meyerson, A.T., Raskin, M.J., Davis, K.L. and Stein, M. (1984) Lymphocyte Function in Major Depressive Disorder. Archives of General Psychiatry, 41, 484-486. https://doi.org/10.1001/archpsyc. 1984.01790160070008

[134] Kronfol, Z., Silva, J., Greden, J., Dembinski, S., Gardner, R. and Carroll, B. (1983) Impaired Lymphocyte Function in Depressive Illness. Life Sciences, 33, 241-247. https://doi.org/10.1016/0024-3205(83)90382-X

[135] Van Snick, J. (1990) Interleukin-6: An Overview. Annual Review of Immunology, 8, 253278. https://doi.org/10.1146/annurev.iy.08.040190.001345

[136] Weisse, C.S. (1992) Depression and Immunocompetence: A Review of the Literature. Psychological Bulletin, 111, 475-489. https://doi.org/10.1037/0033-2909.111.3.475

[137] Maes, M., Scharpé, S., Van Grootel, L., Uyttenbroeck, W., Cooreman, W., Cosyns, P., et al. (1992) Higher a 1-Antitrypsin, Haptoglobin, Ceruloplasmin and Lower Retinol Binding Protein Plasma Levels during Depression: Further Evidence for the Existence of an Inflammatory Response during That Illness. Journal of affective disorders, 24, 183-192. https://doi.org/10.1016/0165-0327(92)90066-F

[138] Song, C., Dinan, T. and Leonard, B. (1994) Changes in Immunoglobulin, Complement and Acute Phase Protein Levels in the Depressed Patients and Normal Controls. Journal of Affective Disorders, 30, 283-288. https://doi.org/10.1016/0165-0327(94)90135-X

[139] Stein, M., Miller, A.H. and Trestman, R.L. (1991) Depression and the Immune System. 
Submit or recommend next manuscript to SCIRP and we will provide best service for you:

Accepting pre-submission inquiries through Email, Facebook, LinkedIn, Twitter, etc.

A wide selection of journals (inclusive of 9 subjects, more than 200 journals)

Providing 24-hour high-quality service

User-friendly online submission system

Fair and swift peer-review system

Efficient typesetting and proofreading procedure

Display of the result of downloads and visits, as well as the number of cited articles

Maximum dissemination of your research work

Submit your manuscript at: http://papersubmission.scirp.org/

Or contact health@scirp.org 